\title{
Espondilite anquilosante - um guia prático de achados de imagem para o clínico
}

\author{
Marina Smiderle Gelain ; Marco Antônio Smiderle Gelain²
}

\section{Resumo}

Introdução: A espondilite anquilosante (EA) é uma doença inflamatória crônica que acomete preferencialmente a coluna vertebral, podendo evoluir com rigidez e limitação funcional progressiva do esqueleto axial.

Geralmente se inicia no adulto jovem do sexo masculino e em indivíduos HLA-B27 positivos. A literatura médica é ainda escassa no que tange às manifestações da EA nos exames de imagem. Tais achados imaginológicos são fundamentais para um diagnóstico precoce e acertado, sendo que sua identificação pelo médico clínico contribui para um melhor entendimento da fisiopatologia da doença, impactando em seu sucesso terapêutico.

Métodos: Revisão bibliográfica baseada na literatura especializada, realizada entre sete e 14 de fevereiro de 2016, através da consulta a artigos científicos selecionados no banco de dados do Scielo e da Bireme, a partir das fontes Medline e Lilacs, em língua inglesa e portuguesa. As palavraschave utilizadas foram ankylosing spondylitis, $x$ Ray, CT, RM, imaging. Os critérios de inclusão foram a abordagem das manifestações por imagem da EA. Foram excluídos estudos que relatavam alterações não imaginológicas da doença. Assim, quatro artigos foram selecionados dentre 132 estudos. Resultados: A radiografia e a tomografia computadorizada (TC) avaliam de forma mais eficiente as alterações estruturais crônicas, de modo que a doença ativa é demonstrada apenas pela ressonância magnética. O marco fundamental da EA é a entesopatia - sítio de inserção óssea de tendões, fáscias, cápsulas e ligamentos A inflamação dessas estruturas é seguida por osteíte reacional (edema ósseo) e erosão associada a um processo de reparação tecidual durante o qual pode haver

\footnotetext{
${ }^{1}$ Graduada em Medicina pela Universidade Federal de Ciências da Saúde de Porto Alegre. Email: marinagelain@hotmail.com.

${ }^{2}$ Graduando em Medicina pela Universidade Federal de Ciências da Saúde de Porto Alegre. Email: marcog@ufcspa.edu.br
} 
neoformação óssea com anquilose. As articulações sacroilíacas, que são as mais acometidas, mostram esclerose subcondral precoce e simétrica, sobretudo em seu terço inferior e anterior e a coluna lombar e torácica apresenta acometimento ascendente. A espondilite de Romanus representa a erosão da face anterior dos cantos vertebrais. A perda da concavidade anterior fisiológica dos corpos vertebrais é denominada vértebra quadrada. A ossificação do ligamento longitudinal da coluna vertebral confere o aspecto típico de coluna em bambu. Conclusão: É importante que o médico clínico esteja familiarizado com os achados por imagem da EA. Tal estudo contribui para um melhor prognóstico funcional e qualidade de vida dos indivíduos acometidos.

Palavras Chave: ankylosing spondylitis; x Ray; CT; RM; imaging. 


\section{Títulos}

\subsection{Subtítulo}

Espondilite anquilosante - um guia prático de achados de imagem para o clínico. 


\section{Ankylosing spondylitis - a practical guide to imaging findings for clinical}

\section{Abstract}

Introduction: Ankylosing spondylitis $(A S)$ is a chronic inflammatory disease that mainly affects the spine, which may progress to stiffness and progressive functional limitation of the axial skeleton. Usually starts in young adult male and positive HLA-B27 individuals. The medical literature is still scarce regarding the manifestations of EA in imaging exams. Such imaging findings are essential for early diagnosis and hit, and its identification by the clinician contributes to a better understanding of the pathophysiology of the disease, impacting on your therapeutic success. Methods: Literature review based on literature held between seven and 14 February 2016, by consulting the scientific articles selected in the Scielo database and Bireme, from Medline and Lilacs sources, in English and Portuguese. The keywords used were ankylosing spondylitis, X Ray, CT, MRI imaging. Inclusion criteria were the approach of demonstrations image EA. They excluded studies that reported no changes imaginological disease. Thus, four articles were selected from 132 studies. Results: X-rays and computed tomography $(C T)$ evaluate more effectively the chronic structural changes, so that the active disease is demonstrated only by MRI. The cornerstone of EA is enthesopathy - bone insertion sites of tendons, fascia, capsule and ligaments Inflammation of these structures is followed by osteitis reaction (bone edema) and erosion associated with the tissue repair process during which there may be bone formation with ankylosis. Sacroiliac joints, which are the most affected, show early and symmetrical subchondral sclerosis, especially in its lower and anterior third and the lumbar and thoracic spine shows up involvement. The Romanus spondylitis is erosion of the anterior surface of the vertebral corners. The loss of physiological anterior concavity of the vertebral bodies is called square vertebra.The ossification of the longitudinal ligament of the spine gives the typical appearance column in bamboo. Conclusion: It is important that the clinician is familiar with the findings by image EA. This study contributes to a better functional outcome and quality of life of affected individuals. 
Keywords: ankylosing spondylitis, $x$ Ray, CT, RM, imaging. 


\section{Referências}

BOONEN A, CRUYSSEN BV, DE VLAM K, et al. Spinal radiographic changes in ankylosing spondylitis: association with clinical characteristics and functional outcome. J Rheumatol 2009;36:1249-55.

ATAGUNDUZ P, AYDIN SZ, BAHADIR C, ERER B, DIRESKENELI $\mathrm{H}$. Determinants of early radiographic progression in ankylosing spondylitis. $J$ Rheumatol 2010; 37: 2356-61.

BRAUN J, SIEPER J. Ankylosing spondylitis. Lancet 2007; 369: 1379-90.

ZHAO, Jinzhu, ZHENG, Wei, ZHANG, Chao, LI, Jia, LIU, Denghui, XU, Weidong.

Radiographic Hip Involvement in Ankylosing Spondylitis: Factors Associated with Severe Hip Diseases. J Rheumatol 2015;42;106-110 